\title{
PENGARUH PERAN KEPEMIMPINAN DAN DISIPLIN KERJA \\ TERHADAP KINERJA KARYAWAN PADA PERUSAHAAN DAERAH AIR MINUM (PDAM) KABUPATEN KARAWANG
}

\author{
${ }^{1}$ Cecep Hermana, ${ }^{2}$ Uswatun Nurhasanah \\ 1,2 Fakultas Ekonomi Universitas Singaperbangsa Karawang \\ Jalan HS. Ronggowaluyo Telukjambe Timur - Karawang 41361 \\ 1chermana911@staff.unsika.ac.id, 로watunnurhasanah696@gmail.com
}

\begin{abstract}
ABSTRAK
Penelitian ini bertujuan untuk menguji dan menganalisis tentang Pengaruh Peran Kepemimpinan dan Disiplin Kerja terhadap Kinerja Karyawan pada Perusahaan Daerah Air Minum (PDAM) Kabupaten Karawang.

Penelitian ini dilakukan dengan menggunakan metode deskriptif dan verifikatif yaitu mengumpulkan, menyajikan, menganalisis, dan melakukan pengujian hipotesis, serta membuat kesimpulan dan saran. Sampel pada penelitian ini berjumlah 194 dengan menggunakan teknik Proportionate Stratified Random Sampling. Teknik analisis yang digunakan yaitu teknik analisis skala likert dan analisis jalur dengan menggunakan alat bantu Method Of Successive Interval (MSI), Microsoft Office dan SPSS versi 16.

Berdasarkan analisis yang telah dilakukan penelitian ini membuktikan bahwa peran kepemimpinan menunjukkan nilai rata-rata 757,6 dengan kriteria setuju. Disiplin kerja menunjukkan nilai rata-rata 732,2 dengan kriteria setuju. Kinerja karyawan menunjukkan nilai rata-rata 702,8 dengan kriteria setuju. Koefisien korelasi antara variabel peran kepemimpinan dengan disiplin kerja diperoleh nilai sebesar 0,647 yang berarti mempunyai tingkat korelasi yang kuat, positif dan signifikan antara peran kepemimpinan dengan disiplin kerja. Pengaruh secara parsial peran kepemimpinan terhadap kinerja karyawan sebesar 7,6\% lebih rendah dari disiplin kerja yaitu sebesar 59,9\% maka dapat dinyatakan bahwa disiplin kerja lebih banyak memberikan kontribusi terhadap kinerja karyawan dibandingkan peran kepemimpinan. Pengaruh secara simultan peran kepemimpinan dan disiplin kerja terhadap kinerja karyawan sebesar 67,5\% sedangkan sisanya sebesar 32,5\% merupakan pengaruh dari variabel lain yang tidak diteliti.
\end{abstract}

Kata Kunci : Peran Kepemimpinan, Disiplin Kerja, Kinerja Karyawan. 


\title{
PENGARUH PERAN KEPEMIMPINAN DAN DISIPLIN KERJA \\ TERHADAP KINERJA KARYAWAN PADA PERUSAHAAN DAERAH AIR MINUM (PDAM) KABUPATEN KARAWANG.
}

\author{
${ }^{1}$ Cecep Hermana, ${ }^{2}$ Uswatun Nurhasanah \\ 1,2 Fakultas Ekonomi Universitas Singaperbangsa Karawang \\ Jalan HS. Ronggowaluyo Telukjambe Timur - Karawang 41361 \\ 1chermana911@staff.unsika.ac.id, 로watunnurhasanah696@gmail.com
}

\begin{abstract}
The purpose of this research to examine and analyze about the Effect of the Role of Leadership and Work Discipline on Employee Performance in Regional Water Company (PDAM), Karawang Regency.

This research was conducted using descriptive and verificative methods, namely collecting, presenting, analyzing, and testing hypotheses, and making conclusions and suggestions. The sample in this study amounted to 194 by using the Proportionate Stratified Random Sampling technique. The analysis technique used is the Likert scale analysis technique and path analysis using the Method of Successive Interval (MSI) tool, Microsoft Office and SPSS version 16.

Based on the analysis that has been done this research proves that the role of leadership shows an average value of 757.6 with agreed criteria. Work discipline shows an average value of 732.2 with agreed criteria. Employee performance shows an average value of 702.8 with agreed criteria. The correlation coefficient between the leadership role variables with work discipline obtained a value of 0.647 which means that there is a level of strong, positive and significant correlation between leadership roles and work discipline. The partial influence of leadership role on employee performance is $7.6 \%$ lower than work discipline that is equal to $59.9 \%$ so it can be stated that work discipline contributes more to employee performance than leadership role. The simultaneous influence of the role of leadership and work discipline on employee performance by $67.5 \%$ while the remaining $32.5 \%$ is the influence of other variables not examined.
\end{abstract}

Keywords: Leadership role, work discipline, employees' leadership 


\section{A. PENDAHULUAN}

Perusahaan Daerah Air Minum (PDAM) merupakan salah satu perusahaan milik daerah yang berbentuk badan hukum yang mengelola bahan baku air minum sebagai perlindungan kualitas air. Perusahaan tersebut merupakan salah satu unit usaha milik daerah yang bergerak dalam distribusi air bersih bagi masyarakat umum yang terdapat disetiap provinsi, kabupaten maupun kotamadya di seluruh Indonesia.

Perusahaan Daerah Air Minum (PDAM) yang ditetapkan melalui Peraturan Daerah Kabupaten Karawang nomor 013 tahun 1987 tentang Pendirian Perusahaan Daerah Air Minum Kabupaten Karawang. Tujuannya dibentuknya perusahaan daerah, selain sebagai sumber pendapatan daerah juga untuk mendorong pemenuhan aspek kesehatan masyarakat dalam meningkatkan derajat kesehatan melalui penyediaan air minum disamping pendorong pertumbuhan ekonomi.

Sejalan dengan perkembangan teknologi, dalam menjalankan peranannya bagi masyarakat, PDAM Kabupaten Karawang dituntut meningkatkan kualitas pelayanan jasa yang diberikan kepada masyarakat sehingga dapat berguna bagi kelancaran kegiatan dalam perusahaan untuk meningkatkan kinerja perusahaan. PDAM Kabupaten Karawang harus dapat mengambil keputusan yang tepat dalam mengevaluasi dan merencanakan aktivitas perusahaan sehingga dapat meningkatkan efisiensi dan efektivitas perusahaan.

Selama periode tahun 2016 sampai dengan tahun 2017, PDAM Kabupaten Karawang dalam kinerja mengalami penurunan yang disebabkan oleh sosok pemimpin dan disiplin kerja karyanwan.

Dalam menjalankan roda perusahaan, PDAM Kabupaten Karawang perlu memiliki sosok pemimpin yang menjadi panutan karyawan, seringkali kepemimpinan yang tidak mampu menjadi panutan akan membuat perusahaan menjadi tidak baik karena karyawan akan menjadi tidak patuh pada aturan dan ketentuan yang berlaku di lingkungan PDAM Kabupaten Karawang , banyak penelitian yang membuktikan bahwa kepemimpinan menjadi salah satu faktor 
kunci keberhasilan suatu perusahaan. Menurut Yukl (2013), Peran pemimpin dalam proses perubahan dapat dikatakan sebagai sumber kesuksesan proses perubahan karena arah dan tujuan perubahan biasanya ditentukan oleh pemimpin untuk kemudian dilaksanakan oleh seluruh anggota organisasi.

Selain peran seorang pemimpin, disiplin kerja merupakan suatu budaya yang wajib diterapkan dalam perusahaan untuk meningkatkan kinerja karyawan. Disiplin kerja mampu menjadi cerminan dan tolak ukur suatu perusahaan dalam mencapai keberhasilan. Untuk itu, disiplin kerja sangat penting guna menghasilkan kinerja yang baik dalam perusahaan.

Menurut Agus Suryono (2014:335), disiplin kerja adalah kesadaran dan kesediaan pegawai menaati semua peraturan organisasi dan norma-norma sosial yang berlaku. Sedangkan menurut Singodimedjo dalam Edy Sutrisno (2017:86) bahwa disiplin adalah sikap kesediaan dan kerelaan seseorang untuk mematuhi dan mentaati norma-norma peraturan yang berlaku disekitarnya.

Berdasarkan uraian permasalahan di atas mengenai menurunnya kinerja karyawan yang diduga karena beberapa faktor seperti peran kepemimpinan dan disiplin kerja, peneliti tertarik untuk melakukan penelitian dengan judul "Pengaruh Peran Kepemimpinan dan Disiplin Kerja terhadap Kinerja Karyawan pada Perusahaan Daerah Air Minum (PDAM) Kabupaten Karawang”.

\section{B. KAJIAN PUSTAKA}

\section{Manajemen Sumber Daya Manusia}

Menurut Achmad S. Rucky dalam Yulius Eka Agung Seputro (2014:18) bahwa Manajemen sumber daya manusia adalah penerapan secara tepat dan efektif dalam proses akuisisi, pendayagunaan, pengembangan, dan pemeliharaan personil secara efektif untuk mendapatkan tingkat pendayagunaan sumber daya manusia yang optimal oleh organisasi tersebut dalam mencapai tujuan-tujuannya. Menurut Henry Simamora dalam Edy Sutrisna (2017:5), Manajemen sumber daya manusia adalah pendayagunaan, 
pengembangan, penilaian, pemberian balas jasa dan pengelolaan terhadap individu anggota organisasi atau kelompok bekerja.

\section{Kinerja Karyawan}

Menurut Kasmir (2016:182) bahwa kinerja merupakan hasil kerja dan perilaku yang telah dicapai dalam menyelesaikan tugas-tugas dan tanggung jawab yang diberikan dalam suatu periode tertentu. Menurut Mangkunegara (2011:67) bahwa kinerja adalah hasil kerja secara kualitas dan kuantitas yang dicapai oleh seorang pegawai dalam melaksanakan tugasnya sesuai dengan tanggung jawab yang diberikan kepadanya.

Menurut Prawirosentono dalam Lijan Poltak Sinambela (2012:2) bahwa: Kinerja adalah hasil kerja yang dapat dicapai oleh seseorang atau sekelompok orang dalam suatu organisasi, sesuai dengan wewenang dan tanggung jawab masing- masing, dalam rangka upaya mencapai tujuan organisasi bersangkutan secara legal, tidak melanggar hukum dan sesuai dengan moral dan etika.

\section{Peran Kepemimpinan}

Menurut Yukl (2013), Peran pemimpin dalam proses perubahan dapat dikatakan sebagai sumber kesuksesan proses perubahan karena arah dan tujuan perubahan biasanya ditentukan oleh pemimpin untuk kemudian dilaksanakan oleh seluruh anggota organisasi. Menurut Edy Sutrisno (2017:213), Kepemimpinan adalah suatu proses kegiatan seseorang untuk menggerakan orang lain dengan memimpin, membimbing, memengaruhi orang lain, untuk melakukan sesuatu agar dicapai hasil yang diharapkan.

Menurut Andri Feriyanto (2015:94) bahwa: Kepemimpinan merupakan kemampuan memengaruhi orang lain, bawahan atau kelompok, kemampuan mengarahkan tingkah laku bawahan atau kelompok, memiliki kemampuan atau keahlian khusus dalam bidang yang diinginkan oleh kelompoknya, untuk mencapai tujuan organisasi atau kelompok.

Menurut Kartini Kartono (2011:6) bahwa: Kepemimpinan adalah masalah 
relasi dan pengaruh antara pemimpin dan yang dipimpin. Kepemimpinan tersebut muncul dan berkembang sebagai hasil dari interaksi otomatis di antara pemimpin dan individu-individu yang dipimpin (ada relasi interpersonal). Kepemimpinan ini bisa berfungsi atas dasar kekuasaan pemimpin untuk mengajak, mempengaruhi, dan menggerakkan orang-orang lain guna melakukan sesuatu, demi pencapaian tujuan tertentu. Menurut Rahmat Hasbullah (2016:112) bahwa: Kepemimpinan adalah suatu entitas atau kelembagaan yang mengarahkan kerja para anggota organisasi untuk mencapai tujuan organisasi, di mana dengan kepemimpinan dapat mendorong kelompok atau organisasi mencapai tujuan- tujuannya, mampu mengikat, mengharmonisasi, serta mendorong potensi sumber daya organisasi agar dapat bersaing secara baik.

\section{Disiplin Kerja}

Menurut Heidjrachman dan Husnan dalam Lijan Poltak Sinambela (2012:15) bahwa : Disiplin adalah setiap perorangan dan juga kelompok yang menjamin adanya kepatuhan terhadap "perintah" dan berinisiatif untuk melakukan suatu tindakan yang diperlukan seandainya tidak ada "perintah".

Menurut Agus Suryono (2014:335), disiplin kerja adalah kesadaran dan kesediaan pegawai menaati semua peraturan organisasi dan norma-norma sosial yang berlaku.

Menurut Singodimedjo dalam Edy Sutrisno (2017:86) bahwa disiplin adalah sikap kesediaan dan kerelaan seseorang untuk mematuhi dan mentaati norma-norma peraturan yang berlaku disekitarnya.

Menurut Edy Sutrisno (2017:89) bahwa disiplin pegawai adalah perilaku seseorang yang sesuai dengan peraturan, prosedur kerja yang ada atau disiplin adalah sikap, tingkah laku, dan perbuatan yang sesuai dengan peraturan dari organisasi baik tertulis maupun yang tidak tertulis.

Berdasarkan pemaparan di atas, maka disiplin kerja merupakan suatu kesadaran dari diri seseorang dalam menjalankan tugas dan 
tanggungjawabnya dalam bekerja dengan mematuhi dan menaati serta menyesuaikan diri pada peraturan yang berlaku setelah adanya kesepakatan bersama.

\section{METODE PENELITIAN}

Metode deskriptif dilakukan untuk mengemukakan data yang masuk dengan cara dikelompokan dan ditabulasikan, kemudian hasilnya diberikan penjelasan. Metode deskriptif digunakan untuk mengetahui gambaran mengenai peran kepemimpinan, disiplin kerja dan kinerja karyawan. Sedangkan penelitian verifikatif dilakukan untuk mengukur suatu fenomena penelitian dengan menggunakan alat bantu statistik. Adapun metode statistik yang digunakan untuk menganalisis pengaruh antar variabel yang diteliti yaitu menggunakan analisis jalur (path analysis) untuk menguji secara parsial dan simultan dari variabel bebas (independen) terhadap variabel terikat (dependen).

Dalam penelitian ini peneliti menggunakan dua variabel bebas yaitu Peran Kepemimpinan (X1) dan Disiplin Kerja (X2) serta satu variabel terikat yaitu Kinerja Karyawan (Y). Penelitian ini dilakukan pada Perusahaan Daerah Air Minum (PDAM) Kabupaten Karawang.

\section{Definisi Operasional Peran Kepemimpinan}

Menurut Edy Sutrisno (2017:213), Kepemimpinan adalah suatu proses kegiatan seseorang untuk menggerakan orang lain dengan memimpin, membimbing, memengaruhi orang lain, untuk melakukan sesuatu agar dicapai hasil yang diharapkan.

Menurut Edy Sutrisno (2017:219-221) terdapat dimensi yang memengaruhi peran kepemimpinan yaitu peranan yang bersifat interpersonal, peranan yang bersifat informasional dan peranan mengambil keputusan yang 
diuraikan dalam skor jawaban responden terhadap pernyataan-pernyataan dalam kuesioner yang terdiri dari 5 = Sangat Setuju (SS), 4 = Setuju (S), $3=$ Cukup Setuju (CS), 2 = Tidak Setuju (TS), dan 1 = Sangat Tidak Setuju (STS).

\section{Definisi Operasional Disiplin Kerja}

Menurut Edy Sutrisno (2017:89) bahwa disiplin pegawai adalah perilaku seseorang yang sesuai dengan peraturan, prosedur kerja yang ada atau disiplin adalah sikap, tingkah laku, dan perbuatan yang sesuai dengan peraturan dari organisasi baik tertulis maupun yang tidak tertulis.

Menurut Malayu Hasibuan (2010:194) terdapat dimensi disiplin kerja yaitu mematuhi semua peraturan perusahaan, penggunaan waktu secara efektif, tanggung jawab dalam pekerjaan dan tugas dan tingkat absensi yang diuraikan dalam skor jawaban responden terhadap pernyataan-pernyataan dalam kuesioner yang terdiri dari $5=$ Sangat Setuju (SS), $4=$ Setuju (S), $3=$ Cukup Setuju (CS), 2 = Tidak Setuju (TS), dan 1 = Sangat Tidak Setuju (STS).

\section{Definisi Operasional Kinerja Karyawan}

Menurut Kasmir (2016:182) bahwa kinerja merupakan hasil kerja dan perilaku yang telah dicapai dalam menyelesaikan tugas-tugas dan tanggung jawab yang diberikan dalam suatu periode tertentu.

Menurut Kasmir (2016:208-209) terdapat dimensi yang memengaruhi kinerja yaitu kualitas (mutu), kuantitas (jumlah), waktu (jangka waktu), penekanan biaya, pengawasan, dan hubungan antar pegawai yang diuraikan dalam skor jawaban responden terhadap pernyataan-pernyataan dalam kuesioner yang terdiri dari 5 = Sangat Setuju (SS), 4 = Setuju (S), 3 = Cukup Setuju (CS), 2 = Tidak Setuju (TS), dan 1 = Sangat Tidak Setuju (STS).

\section{Populasi dan Sampel}

Populasi dalam penelitian ini sebanyak 377 orang yang diambil dari data karyawan Perusahaan Daerah Air Minum (PDAM) Kabupaten Karawang. 
Oleh karena populasi sudah diketahui jumlahnya, maka untuk menentukan jumlah sampel yang akan diteliti menggunakan rumus :

$$
\begin{gathered}
n=\frac{N}{1+N(e)^{2}} \\
n=\frac{377}{1+377(0.05)^{2}} \\
n=\frac{377}{1.94} \\
n=194,32
\end{gathered}
$$

Berdasarkan pertimbangan dari hasil perhitungan di atas maka peneliti menggenapkan total sampel menjadi 194 orang.

\section{Metode Pengumpulan Data}

Dalam penelitian ini, data yang digunakan adalah data primer, data ini dikumpulkan dengan cara menyebarkan kuesioner dengan scoring model likert. Data didapat dengan cara datang langsung karyawan Perusahaan Daerah Air Minum (PDAM) Kabupaten Karawang.

\section{HASIL DAN PEMBAHASAN}

\section{Pembahasan Deskriptif}

a. Berdasarkan hasil penelitian menunjukkan bahwa variabel peran kepemimpinan pada Perusahaan Daerah Air Minum (PDAM) Kabupaten Karawang diperoleh total skor sebesar 11.365 dengan rata-rata skor sebesar 757,6 berada pada rentang skala 659,6 - 814,8 artinya berada pada kriteria setuju. Indikator yang memiliki skor tertinggi yaitu indikator selaku pemimpin yang memberi contoh seperti pemimpin ikut terjun kelapangan, disiplin waktu datang ke kantor, ramah dan rendah hati terhadap karyawannya. Indikator yang memiliki skor terendah yaitu 
indikator menerima informasi dan dalam penempatan karyawan. Hal tersebut menunjukkan bahwa peran kepemimpinan pada Perusahaan Daerah Air Minum (PDAM) Kabupaten Karawang sudah baik dan mampu meningkatkan kinerja karyawan melalui peran kepemimpinan. Hal itu sesuai dengan pendapat yang dikemukakan Edy Sutrisno (2017:213) bahwa Kepemimpinan adalah suatu proses kegiatan seseorang untuk menggerakan orang lain dengan memimpin, membimbing, memengaruhi orang lain, untuk melakukan sesuatu agar dicapai hasil yang diharapkan.

b. Berdasarkan hasil penelitian menunjukkan bahwa variabel disiplin kerja pada Perusahaan Daerah Air Minum (PDAM) Kabupaten Karawang diperoleh total skor sebesar 10.983 dengan rata-rata skor sebesar 732,2 berada pada rentang skala 659,6 - 814,8 yang artinya berada pada kriteria setuju. Seluruh indikator sudah berada dalam kriteria setuju, indikator yang memiliki skor tertinggi yaitu indikator tanggungjawab dalam bekerja seperti melakukan pekerjaan yang diperintahkan kepadanya, menyelesaikannya serta bekerja sesuai jabatannya. Indikator yang memiliki skor terendah yaitu indikator kemangkiran. Hal tersebut menunjukkan bahwa disiplin kerja pada Perusahaan Daerah Air Minum (PDAM) Kabupaten Karawang sudah baik dan mampu meningkatkan kinerja karyawan melalui disiplin kerja. Hal itu sesuai dengan pendapat yang dikemukakan Edy Sutrisno (2017:89) bahwa disiplin pegawai adalah perilaku seseorang yang sesuai dengan peraturan, prosedur kerja yang ada atau disiplin adalah sikap, tingkah laku, dan perbuatan yang sesuai dengan peraturan dari organisasi baik tertulis maupun yang tidak tertulis.

c. Berdasarkan hasil penelitian menunjukkan bahwa variabel kinerja karyawan pada Perusahaan Daerah Air Minum (PDAM) Kabupaten Karawang diperoleh total skor sebesar 10.542 dengan rata-rata skor sebesar 702,8 berada pada rentang skala 659,6 - 814,8 yang artinya berada pada kriteria setuju. Hal tersebut menunjukkan bahwa upaya meningkatkan kinerja karyawan pada Perusahaan Daerah Air Minum 
(PDAM) Kabupaten Karawang sudah baik. Namun masih terdapat 3 indikator yang menjawab cukup setuju yaitu pada indikator melebihi target perusahaan dengan skor sebesar 619, indikator mengurangi aktivitas yang menghambat waktu bekerja dengan skor sebesar 656 dan pengawasan dalam bekerja dengan skor sebesar 658. Kemudian diperoleh Indikator yang memiliki skor tertinggi yaitu indikator kemampuan menyelesaikan pekerjaan memperoleh skor sebesar 756 dan indikator yang memiliki skor terendah yaitu indikator melebihi target perusahaan memperoleh skor sebesar 619. Hal tersebut sesuai dengan pendapat yang dikemukakan Kasmir (2016:182) bahwa kinerja merupakan hasil kerja dan perilaku yang telah dicapai dalam menyelesaikan tugas-tugas dan tanggung jawab yang diberikan dalam suatu periode tertentu.

\section{Pembahasan Verifikatif}

Adapun pembahasan dari metode verifikatif dalam penelitian ini dapat diuraikan sebagai berikut:

a. Pengaruh secara parsial peran kepemimpinan terhadap kinerja karyawan didapatkan koefisien jalur sebesar 0,126 dan pengaruh secara parsial terhadap kinerja karyawan sebesar 7,6\%. Hal tersebut sejalan dengan penelitian yang dilakukan Dinda Sri Damayanti (2017) membuktikan bahwa peran kepemimpinan memliki pengaruh positif dan signifikan terhadap kinerja pegawai. Serta sesuai dengan yang dikemukakan Kasmir (2016:191) jika perilaku pemimpin tidak menyenangkan, tidak mengayomi, tidak mendidik, dan tidak membimbing akan menurunkan kinerja pegawai. Jadi, kepemimpinan mempengaruhi kinerja.

b. Pengaruh disiplin kerja terhadap kinerja karyawan didapatkan koefisien jalur sebesar 0,734 dan pengaruh secara parsial terhadap kinerja karyawan sebesar 59,9\%. Hal tersebut sejalan dengan penelitian yang dilakukan I Nyoman Jaka Alit Wiratama dan Desak Ketut Sintaasih (2013) membuktikan bahwa disiplin kerja memliki pengaruh positif dan signifikan terhadap kinerja pegawai. Serta sesuai dengan yang 
dikemukakan Kasmir (2016:193) disiplin kerja dalam hal ini dapat berupa waktu, misalnya masuk kerja selalu tepat waktu. Kemudian disiplin mengerjakan apa yang diperintahkan kepadanya sesuai dengan perintah yang harus dikerjakan. Pegawai yang disiplin akan memengaruhi kinerja.

c. Pengaruh secara simultan peran kepemimpinan dan disiplin kerja terhadap kinerja karyawan pada Perusahaan Daerah Air Minum (PDAM) Kabupaten Karawang sebesar 0,675 atau 67,5\% sedangkan sisanya 0,325 atau $32,5 \%$ merupakan pengaruh variabel lain yang tidak diteliti dalam penelitian ini. Hal tersebut sejalan dengan penelitian yang dilakukan Dinda Sri Damayanti (2017) membuktikan bahwa peran kepemimpinan dan disiplin kerja bersama-sama memiliki pengaruh positif dan signifikan terhadap kinerja pegawai. Serta sesuai dengan yang dikemukakan Kasmir (2016:189-193) bahwa terdapat beberapa faktor yang memengaruhi kinerja pegawai, diantaranya: kemampuan dan keahlian, pengetahuan, rancangan kerja, kepribadian, kepemimpinan, gaya kepemimpinan, dan disiplin kerja.

Dengan demikian pengaruh secara parsial antara peran kepemimpinan terhadap kinerja karyawan sebesar 7,6\% lebih rendah dari pengaruh disiplin kerja terhadap kinerja karyawan sebesar 59,9\%.

\section{E. KESIMPULAN}

Berdasarkan hasil penelitian, pengumpulan data dan pembahasan hasil analisa, maka dapat ditarik kesimpulan sebagai berikut:

1. Terdapat pengaruh secara parsial dari Peran Kepemimpinan dan Disiplin Kerja terhadap Kinerja Karyawan pada Perusahaan Daerah Air Minum (PDAM) Kabupaten Karawang dengan rincian sebagai berikut:

a. Pengaruh peran kepemimpinan terhadap kinerja karyawan sebesar 7,6\% sehingga dapat disimpulkan bahwa peran kepemimpinan berpengaruh signifikan secara parsial terhadap kinerja karyawan. 
b. Pengaruh disiplin kerja terhadap kinerja karyawan sebesar 59,9\% sehingga dapat disimpulkan bahwa disiplin kerja berpengaruh signifikan secara parsial terhadap kinerja karyawan.

Dengan demikian pengaruh secara parsial antara disiplin kerja terhadap kinerja karyawan sebesar 59,9\% lebih tinggi dari pengaruh peran kepemimpinan terhadap kinerja karyawan sebesar 7,6\%.

2. Terdapat pengaruh Secara Simultan Peran Kepemimpinan dan Disiplin Kerja terhadap Kinerja Karyawan pada Perusahaan Daerah Air Minum (PDAM) Kabupaten Karawang yaitu sebesar $67,5 \%$ sedangkan sisanya 32,5\% merupakan pengaruh variabel lain yang tidak diteliti dalam penelitian ini.

\section{DAFTAR PUSTAKA}

Dessler, G. 2013. Human Resource Management (13th ed.). Florida: Pearson.

FEB Unsika. 2015. Buku Panduan Penulisan Skripsi S1 Manajemen Edisi 7. Karawang: Fakultas Ekonomi dan Bisnis Universitas Singaperbangsa Karawang.

Feriyanto, Andri dan Triana, Endang Shiyta. 2015. Pengantar Manajemen (3 in 1).

Kebumen : Medika Tera.

Hasbullah, Rahmat dan Wanarni, Srihadi. 2016. Mengelola perilaku dalam organisasi (Tantangan dan Peluang). Karawang: Badan Penerbit Fakultas Ekonomi dan Bisnis UNSIKA.

Hasibuan, Malayu. 2017. Manajemen Sumber Daya Manusia. Jakarta: Bumi Aksara.

Kartono, Kartini. 2011. Pemimpin dan kepemimpinan : apakah kepemimpinan abnormal itu ?. jakarta: Rajawali Pers.

Kasmir. 2016. Manajemen Sumber Daya Manusia (Teori dan Praktik). Jakarta: PT RayaGrafindo Persada.

Rivai, Veithzal, dkk. 2008. Performance Appraisal. Jakarta: RajaGrafindo Persada. Sinambela, Lijan Poltak. 2016. Manajemen Sumber Daya Manusia. Jakarta: Bumi Aksara. Sopiah. 2008. Perilaku Organisasi. Yogyakarta: ANDI.

Sugiyono. 2014. Metode penelitian kuantitatif, kualitatif dan R\&D. Bandung: Alfabeta. Sugiyono. 2015. Metode penelitian kuantitatif, kualitatif dan R\&D. Bandung: Alfabeta. Sugiyono. 2017. Metode penelitian kuantitatif, kualitatif dan R\&D. Bandung: Alfabeta. Sutrisno, Edy. 2017. Manajemen Sumber Daya Manusia. Jakarta: Kencana.

Yukl, G. 2013. Leadership in Organization. England: Pearson.

Aprianti, Nur Endah. 2017. Pengaruh Peran Kepemimpinan terhadap Kedisiplinan Kerja serta Dampaknya Pada Kinerja Pegawai Pada PT Sang Hyang Seri (Persero) 
Kabupaten Subang. Skripsi. Jurusan Manajemen Universitas Singaperbangsa Karawang.

Damayanti, Dinda Sri. 2017. Pengaruh Peran Kepemimpinan dan Disiplin Kerja Terhadap Kinerja Pegawai Pada PT Kaneka Foods Indonesia. Skripsi. Jurusan Manajemen Universitas Singaperbangsa Karawang.

Fitri, Dhea Karina dan Sudharto P. Hadi. 2016. Pengaruh Disiplin Kerja dan Motivasi terhadap Kinerja Pegawai Perusahaan Daerah Air Minum Tirta Amerta Kabupaten Blora. Jurnal. Departemen ilmu administrasi bisnis fakultas ilmu sosial dan ilmu politik universitas diponegoro.

Hafid, Haeruddin. 2018. Pengaruh Kompetensi, Kepemimpinan Dan Disiplin Kerja Terhadap Kinerja Pegawai Pada Samsat Poliwali Mandar. Jurnal. STIE Muhammadiyah Mamuju.

Suganda, Dedi. 2011. Strategi Pengembangan Perusahaan Daerah Air Minum (PDAM) Dalam Upaya Meningkatkan Cakupan Pelayanan Air Minum Kepada Masyarakat Di Kabupaten Karawang (Studi Kasus pada PDAM Kabupaten Karawang). Tesis. Program Magister Manajemen Universitas Singaperbangsa Karawang.

Warniah. 2018. Pengaruh Lingkungan Kerja Dan Disiplin Kerja Terhadap Kinerja Karyawan Pada PT Canvas Industry Indonesia. Skripsi. Jurusan Manajemen Universitas Singaperbangsa Karawang.

Wibowo, Restu Yuliani. 2013. Peran Kepemimpinan Dalam Meningkatkan Kedisiplinan Pegawai Pada Badan Penanaman Modal Daerah Jawa Tengah. Skripsi. Jurusan Manajemen. Fakultas Ekonomi Universitas Negeri Semarang.

Wiratama, I Nyoman Jaka Alit dan Sintaasih, Desak Ketut. 2013. Pengaruh Kepemimpinan, Diklat Dan Disiplin Kerja Terhadap Kinerja Karyawan PDAM Tirta Mangutama Kabupaten Badung. Jurnal. Fakultas Ekonomi Universitas Udayana Bali.

Gunawan, Iwan. 5 Oktober 2018. Air Kecil, Tagihan Membengkak, Pelanggan PDAM Tirta Tarum Kabupaten Karawang Kecewa, Dalam Situs: https://jabar.pojoksatu.id/pantura/2018/10/05/air-kecil-tagihanmembengkak-pelanggan-pdam-tirta-tarum-kabupaten-karawangkecewa/2/diakses pada tanggal 21 Februari 2019 Pukul 17.15 WIB.

PDAM Tirta Tarum Karawang. Dalam situs https://pamkarawang.com diakses pada tanggal 20 Februari 2019 Pukul 11.24 WIB.

Rencana Strategis Badan Peningkatan Penyelenggaraan Sistem Penyediaan Air Minum (BPPSPAM) Tahun 2018-2022. Dalam situs http://sim.ciptakarya.pu.go.id/ diakses pada tanggal 22 Februari 2019 Pukul 17.14 WIB.

Kegiatan-Kegiatan PDAM Tirta Tarum Karawang BEST (Berikan Servise Terbaik!). Dalam situs https://www.pdamkarawang.com/ diakses pada tanggal 24 Agustus 2019 Pukul 21.28 WIB.

Kinerja PDAM 2018. Dalam situs http://sim.ciptakarya.pu.go.id/bppspam/ diakses pada tanggal 24 Februari 2019 Pukul 18.15 WIB. 
Buku Laporan Evaluasi Kinerja PDAM 2017. Dalam situs http://sim.ciptakarya.pu.go.id/ dengan nama BUKU_Lap_Kinerja_PDAM_2017_FA.pdf diakses pada tanggal 25 Februari 2019 pukul 18.22 WIB.

Buku Kinerja Wilayah 2. Dalam situs https://kupdf.net/download/kinerja-pdamwilayah- 2 258c9f09bdc0d6054833902c_pdf diakses pada tanggal 25 Februari 2019 pukul 18.37 WIB.

Peraturan Direksi Perusahaan Daerah Air Minum “Tirta Tarum” Kabupaten Karawang Nomor 800/PER.267/PDAM (Peraturan Kepegawaian).

Laporan Bulanan Pegawai PDAM Kabupaten Karawang 2014-2018. Rekapitulasi Absensi pegawai PDAM Kabupaten Karawang Tahun 2014-2018. Kinerja PDAM Tahun 2018. 